\title{
Mercury in till and bedrock southeast of Kejimkujik National Park, Nova Scotia
}

\author{
Belinda M. Culgin ${ }^{1^{*}}$ And Terry A. Goodwin ${ }^{2}$ \\ 1. 983 Pickering Beach Road, Ajax, Ontario L1S 1G2, Canada <bculgin@golder.com> \\ 2. Nova Scotia Department of Natural Resources, 1701 Hollis St., P.O. Box 698, \\ Halifax, Nova Scotia B3J 2T9, Canada <goodwita@gov.ns.ca> \\ * Corresponding author
}

Date received:22 December 2005 Date accepted: 18 October 2006

\begin{abstract}
Loons in Kejimkujik National Park, located in southwestern Nova Scotia, contain the highest mercury concentrations in blood of any breeding loon population tested in North America. A team of multi-disciplinary scientists has completed extensive research within and around the park in an attempt to identify the source(s) and process(es) that may be responsible for the high levels of mercury. One aspect of the research involved the collection of $32 \mathrm{C}$-horizon till samples from depths ranging from 70 to $120 \mathrm{~cm}$. The samples were collected at 100 to $200 \mathrm{~m}$ intervals from three northwest-southeast transects that cross the inferred contact between the Halifax and Goldenville formations south of the Kejimkujik National Park boundary. Geochemical analysis ( $<63 \mu \mathrm{m}$ size fraction) of the till indicates that the mean $\mathrm{Hg}$ concentrations are $40.8 \mathrm{ppb}$ for till overlying slate of the Halifax Formation, and $32.4 \mathrm{ppb}$ for till overlying greywacke of the Goldenville Formation. Chemical analyses of 9 bedrock samples $(<105 \mu \mathrm{m}$ size fraction) returned very low $\mathrm{Hg}$ concentrations (mean $2.4 \mathrm{ppb}$ ). Strict quality assurance/quality control protocols were followed in the collection, preparation, and analysis of the till and bedrock samples.
\end{abstract}

\section{RÉSUMÉ}

Les huards du parc national Kejimkujik, situé dans le Sud de la Nouvelle-Écosse, présentent les concentrations de mercure dans le sang les plus élevées parmi toutes les populations de huards examinées en Amérique du Nord. Une équipe pluridisciplinaire de scientifiques a réalisé des travaux de recherche approfondis à l'intérieur et à proximité du parc pour tenter de repérer la ou les sources et le ou les processus à l'origine des concentrations élevées de mercure. Un volet de ces recherches a comporté le prélèvement de 32 échantillons de till de l'horizon C à des profondeurs variant entre 70 et $120 \mathrm{~cm}$. Les échantillons ont été prélevés à des intervalles de 100 à $200 \mathrm{~m}$ à l'intérieur de trois transects du nord-ouest au sud-est traversant la présumée zone de contact entre les formations d'Halifax et de Goldenville, au sud de la limite du parc national Kejimkujik. Une analyse géochimique (fraction d'une dimension de moins de $63 \mu \mathrm{m}$ ) du till révèle des concentrations moyennes de $\mathrm{Hg}$ de 40,8 p.p. $10^{9}$ b dans le till recouvrant l'ardoise de la Formation d'Halifax et de 32,4 p.p. $10^{9}$ dans le till recouvrant la grauwacke de la Formation de Goldenville. Des analyses chimiques de neuf échantillons de substrat rocheux (fraction d'une dimension de moins de $105 \mu \mathrm{m}$ ) ont accusé des concentrations très faibles de $\mathrm{Hg}$ (en moyenne 2,4 p.p. $10^{9}$ ). Les chercheurs ont suivi des protocoles rigoureux d'assurance/de contrôle de la qualité lors du prélèvement, de la préparation et de l'analyse des échantillons de till et de roche du substratum.

[Traduit par la rédaction]

\section{INTRODUCTION}

Loons in Kejimkujik National Park (KNP), southwestern Nova Scotia, have the highest mercury $(\mathrm{Hg})$ concentration in blood of any breeding loon population in North America (Burgess et al. 1998, 2005; Burgess and Hobson 2006). For the past several years, a multi-disciplinary team of research scientists has been attempting to identify the potential Hg source(s) and process(es) responsible for the anomalous Hg levels. A geochemical component of this research involved the collection and chemical analysis of till and bedrock samples to quantify the geogenic contribution of naturally occurring $\mathrm{Hg}$ concentrations from glacial sediments overlying bedrock sources within the Meguma Group, in particular the Goldenville Formation - Halifax Formation Transition Zone (GHTZ).

The study, located on N.T.S. map sheet $21 \mathrm{~A} / 06$, just south of the Kejimkujik National Park boundary, was divided into three components: 1) bedrock and surficial mapping of the various stratigraphic units, 2) till and bedrock geochemical sampling/analysis, and 3) a detailed ground magnetic survey 
to accurately locate the contact between the Goldenville and Halifax formations.

\section{BEDROCK GEOLOGY}

The study area is located just south of Kejimkujik National Park and is underlain by rocks of the Meguma Group (Fig. 1). Outcrop exposure is rare $(<2 \%)$ and found mainly along roadside ditches and watercourses. The oldest rocks consist of massive grey to green greywacke and minor laminated grey to black metasiltstone of the Goldenville Formation. These are overlain by finely laminated greenish grey to black slate and metasiltstone of the Halifax Formation (Williams et al. 1985; Horne and Corey 1994).

The contact between the coarse-grained Goldenville
Formation and fine-grained Halifax Formation is gradational and referred to as the Goldenville - Halifax Transition Zone. The GHTZ is known for its distinctive rock types characterized by a Mn-rich, spessartine garnet-bearing, coticule horizon interstratified with slate and greywacke (Graves and Zentilli 1988). The GHTZ is characterized geochemically by the presence of anomalous concentrations of metals including $\mathrm{Mn}$, $\mathrm{Ba}, \mathrm{Pb}, \mathrm{Zn}, \mathrm{Cu}, \mathrm{Mo}, \mathrm{W}$, and $\mathrm{Au}$ (Graves and Zentilli 1988). The GHTZ is further characterized by layers rich in pyrite and pyrrhotite that may play an important role in $\mathrm{Hg}$ cycling when sulphide mineral oxidation allows the release of metals in the environment (Fox et al. 1997). The contact between the Halifax and Goldenville formations is not exposed in the study area. Devonian monzogranite, namely the Scrag Lake and Kejimkujik plutons, and leucomonzogranite, the Davis

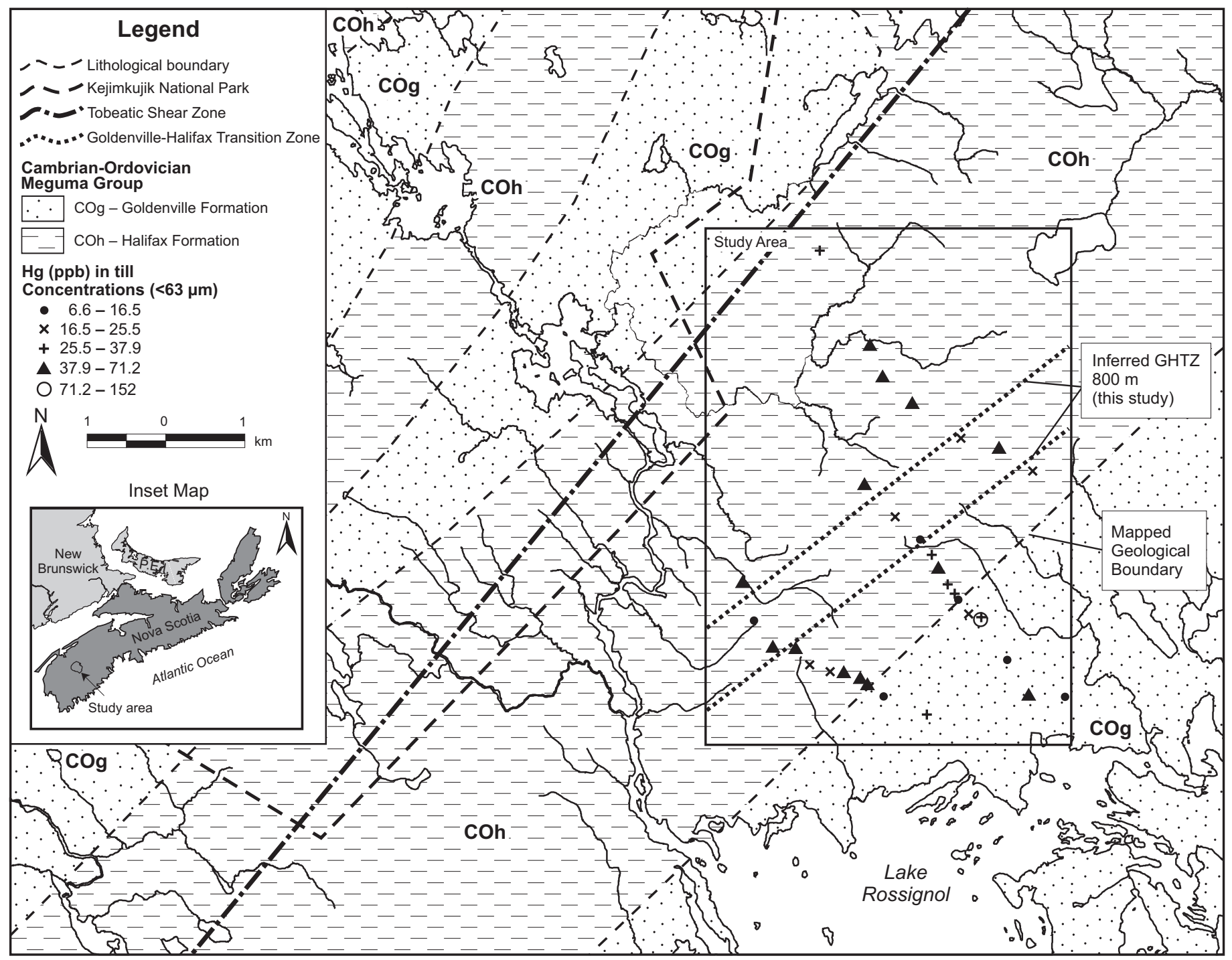

Fig. 1 Bedrock geology of the study area and part of Kejimkujik National Park, showing the location of the inferred Goldenville - Halifax Transition Zone (GHTZ) and the position of the actual mapped contact. Till sample locations with Hg concentrations (ppb) are shown along the three transects. Geology after Horne \& Corey (1994). 
Lake Pluton, intruded the Halifax and Goldenville formations (Horne and Corey 1994).

\section{SURFICIAL GEOLOGY}

The surficial geology of the study area is characterized by the Late to Middle Wisconsinan Beaver River Till (Finck et al. 1994). Two facies of the Beaver River Till are present in the study area, the clay-rich slate facies derived from slate of the Halifax Formation and the sandy greywacke facies derived from metasedimentary rocks of the Goldenville Formation. The major glacial transport direction for the Beaver River Till is southeastward over the South Mountain Batholith with a short dispersal distance $(<1 \mathrm{~km})$, resulting in a locally derived till varying in thickness from 1 to $6 \mathrm{~m}$. During the field mapping and sampling program, ice-flow indicators such as glacial striations were identified and recorded confirming the regional transport direction of Stea (1982).

\section{PREVIOUS WORK}

Smith (2000) reported that the average Hg concentration in bedrock in southwestern Nova Scotia is $3.3 \mathrm{ppb}(\mathrm{n}=146)$. The mean $\mathrm{Hg}$ content in greywacke of the Goldenville Formation is lowest (1.0 ppb), closely followed by granite (1.5 ppb), and slate of the Halifax Formation (2.5 ppb). The highest Hg concentrations are in the biotite separates from monzogranite (13.8 ppb) and Silurian rocks (diabase dykes, sills, and associated siltstone) from the Bear River area (12.2 ppb). Page and Murphy (2003) postulated that biotite in granite may be a significant contributor to distribution and migration of $\mathrm{Hg}$ in southwestern Nova Scotia. In another study, unweighted averages for various rock types in Kejimkujik National Park indicate that the average Hg concentration is in the order of $4.4 \mathrm{ppb}$ (Smith et al. 2005).

Sangster et al. (2001) summarized the $\mathrm{Hg}$ concentrations in different lithologies throughout Kejimkujik National Park, including data from drill core from the eastern part of the Meguma Terrane. They observed that the lowest Hg concentrations are in the Goldenville Formation $(<0.5 \mathrm{ppb}$ to $4.0 \mathrm{ppb}$; $\mathrm{n}=$ $47)$ and in monzogranite of the Kejimkujik Pluton $(<0.5 \mathrm{ppb}$ to $5.8 \mathrm{ppb} ; \mathrm{n}=31$ ). They also observed that the Halifax Formation had slightly higher $\mathrm{Hg}$ concentrations, ranging from $<0.5 \mathrm{ppb}$ to $16.4 \mathrm{ppb}(\mathrm{n}=100)$. Sangster et al. $(2001)$ concluded that $\mathrm{Hg}$ could be transferred during the earliest weathering stages and is most pronounced in the porous, well-cleaved, sulphidic black slate that contains $5 \%$ pyrite and/or pyrrhotite. The higher concentrations of $\mathrm{Hg}$ observed in drill core samples suggest that surface bedrock sampling may not accurately account for all the $\mathrm{Hg}$ present in the bedrock, as significant amounts may have been leached during secondary weathering processes (Sangster et al. 2001). Goodwin (2005) reported the results of $\mathrm{Hg}$ concentrations for ninety-seven till samples collected mostly from within Kejimkujik National Park.

\section{METHODOLOGY}

During the summer of 2001, a geochemical, geological, and geophysical field program was completed in the study area. This involved (1) till and bedrock sampling, (2) geological mapping and (3) approximately $11 \mathrm{~km}$ of detailed total field ground magnetic surveying. Three NW-SE transects ranging from $2.3 \mathrm{~km}$ to $3.7 \mathrm{~km}$ in length that crossed the inferred Halifax Formation - Goldenville Formation contact were used for control of this contact zone (Fig. 1).

A total of $32 \mathrm{C}$ horizon till samples were collected at 100 to $200 \mathrm{~m}$ intervals from the same three NW-SE transects used for the detailed total field ground magnetic survey. Samples were collected by shovel at depths ranging from 70 to $120 \mathrm{~cm}$, which is beyond the depth of anthropogenic atmospheric influence (Henderson and McMartin 1995). Till clast identification and counts were completed on 11 samples collected from transects two and three. Nine rock samples were collected from exposed slate and greywacke outcrops along the same transects.

Sieved till ( $<63$ microns) and crushed rock samples $(<105$ microns) were digested in aqua regia and analyzed for $\mathrm{Hg}$ by CETAC Cold Vapour Atomic Absorption (34 additional elements) with a lower detection limit of $1 \mathrm{ppb}$, by ACME Analytical Laboratories Ltd., Vancouver, B.C. Particular attention was given to quality control protocols during the entire program. This control included the insertion of certified standards, preparation splits and field duplicates (representing about $15 \%$ of the samples submitted for analysis) during the collection, preparation, and analysis of the till and rock samples.

Total field magnetic readings were acquired at $12.5 \mathrm{~m}$ spacing along each of the three traverses crossing the inferred Halifax Formation - Goldenville Formation contact(Fig.1). All readings were subsequently corrected for diurnal drift.

\section{RESULTS AND DISCUSSION}

\section{Till geochemistry}

The highest reported $\mathrm{Hg}$ concentration from the 32 till samples was in till derived from the Halifax Formation slate. Mercury concentrations ranged from a low of $13.2 \mathrm{ppb}$ to a high of $151.5 \mathrm{ppb}(\mathrm{n}=20$; mean $40.8 \mathrm{ppb} ; \sigma=31.12$; Fig. 2a). Till derived from the Goldenville Formation metasandstone contains $\mathrm{Hg}$ concentrations ranging from $6.6 \mathrm{ppb}$ to $71.2 \mathrm{ppb}$ $(\mathrm{n}=12$; mean $32.4 \mathrm{ppb} ; \sigma=19.21$; Fig. $2 \mathrm{~b}$ ). Till sample locations with associated proportional symbol plots for $\mathrm{Hg}$ concentrations are presented in Fig. 1. Mean Hg in till concentrations from this study are slightly lower than mean $\mathrm{Hg}$ content for till 
a) $\quad \mathrm{Hg}$ in Beaver River till overlying the Halifax Formation slate

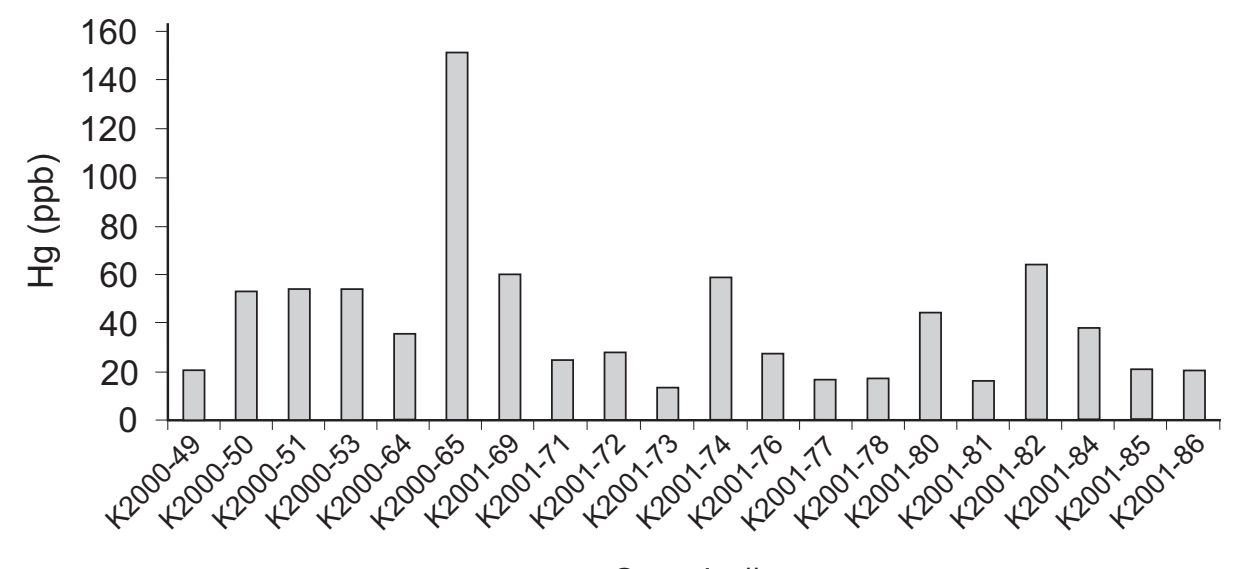

Sample \#

b) $\mathrm{Hg}$ in Beaver River till overlying the Goldenville Formation greywacke

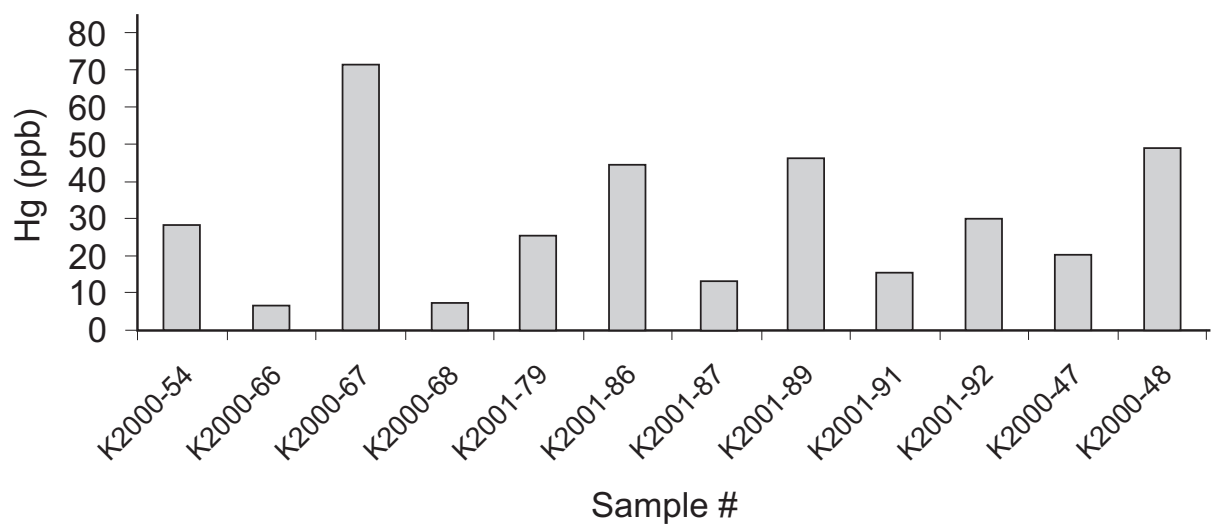

Fig. 2 Mercury concentrations in (a) the clay-rich slate facies of the Beaver River till and (b) the sandy greywacke facies of the Beaver River till.

(50 ppb) reported by Jonasson and Boyle (1972). Complete geochemical and geo-referenced data for the study area are available in tabular format in Culgin (2002).

\section{Clast identification and counts}

The clast identification and counts from the $>4 \mathrm{~mm}$ pebble fraction of eleven till samples confirm the presence in the study area of two facies of the Beaver River Till (Finck et al. 1994), a clay-rich slate facies and a sandy greywacke facies (Fig. 3). The generally southeast ice-flow direction was also confirmed and a dispersal distance of approximately $900 \mathrm{~m}$ was determined on the basis of the percentage ( $>50 \%$ ) of greywacke clasts downice from the contact of the Halifax/Goldenville formations. The contact was interpreted from the total field magnetic survey. The $x-y$ plot (Fig. 3) of the relative proportion of Halifax
Formation slate clasts recovered from till samples indicates that the relative width of the Halifax Formation slate subcropping in the study area may be significantly less than shown on the most recent published geology map (Horne and Corey 1994).

\section{Rock geochemistry}

A total of nine bedrock samples were collected and subsequently analyzed for $\mathrm{Hg}$ during this study. All rock samples returned low $\mathrm{Hg}$ concentrations ranging from $0.2 \mathrm{ppb}$ to $3.4 \mathrm{ppb}$ (mean $2.4 \mathrm{ppb} ; \mathrm{n}=9 ; \sigma=0.91 ;$ Fig. 4) including two samples of black slate containing significant $(>5 \%)$ sulphide mineralization. On the basis of only two samples, a correlation between the sulphidic black slates and $\mathrm{Hg}$ concentration is not possible. Mercury concentrations for the nine rock samples collected during this study are significantly below the mean 


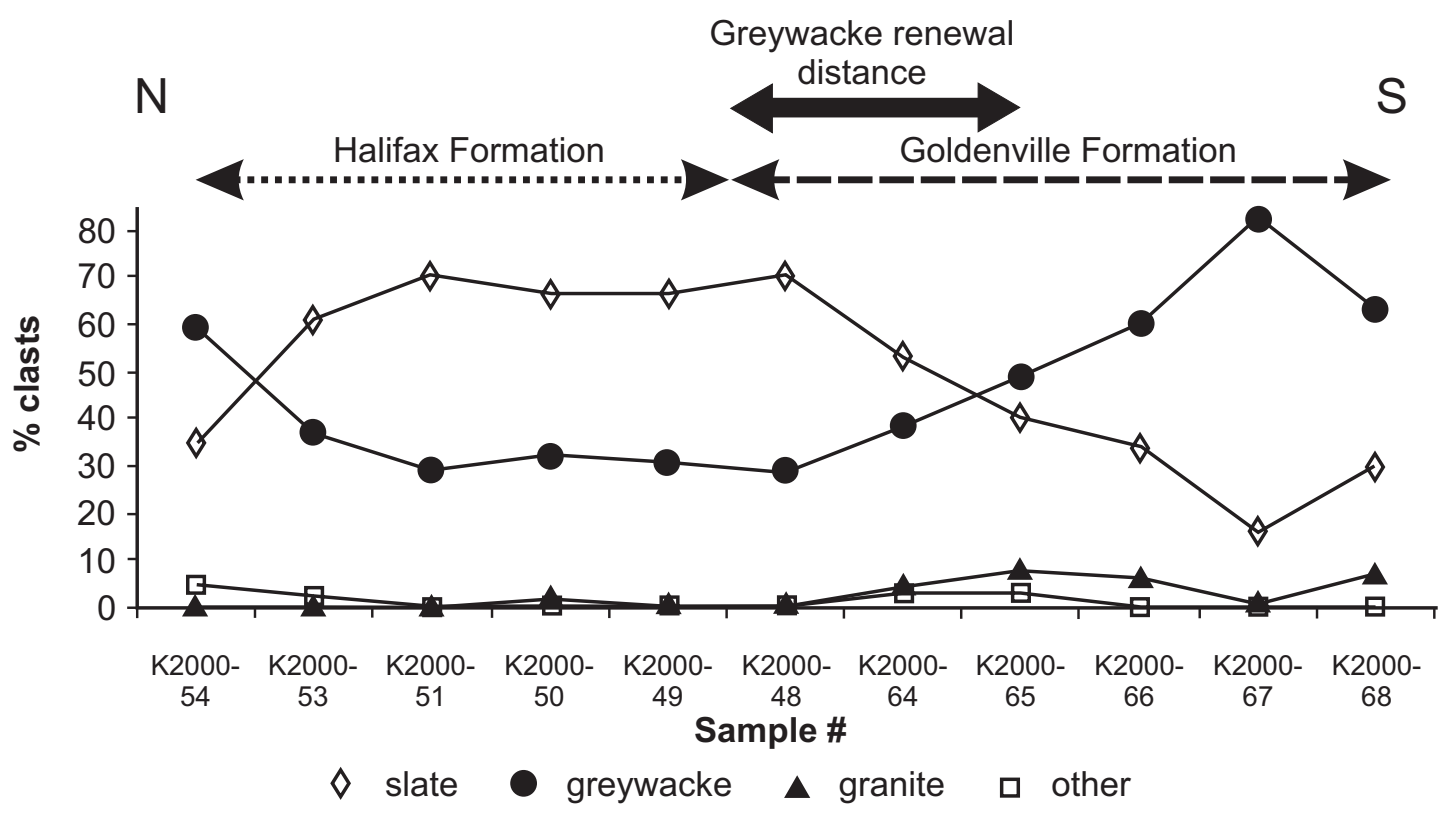

Fig. 3 Till clast counts $(>4 \mathrm{~mm})$ recovered from till samples collected along transect 2 and 3 and projected into the same profile. The distance between samples is approximately $200 \mathrm{~m}$. The greywacke renewal distance is estimated to be approximately $900 \mathrm{~m}$. Bedrock geology of the Goldenville and Halifax groups represented by large dashed and dotted arrows, respectively, at the top of the figure. The solid black arrow indicates the greywacke renewal distance $(\sim 900 \mathrm{~m})$.

Hg content of quartzite (53 ppb) and schist (100 ppb) reported by Jonasson and Boyle (1972). Smith (2000) reported a slightly higher mean $\mathrm{Hg}$ concentration of $3.3 \mathrm{ppb}$ for a broader suite of rock types.

\section{Geophysics: ground magnetic survey}

The GHTZ is in part characterized by increased magnetic susceptibility relative to the Halifax and Goldenville formations (King 1997). The GHTZ, therefore, is a unique magnetic marker horizon readily identifiable on both airborne and ground magnetic surveys. Interpreted results of the detailed total field ground magnetic survey indicate that the Halifax and Goldenville formations are characterized by magnetic responses of similar amplitude (Fig. 5). The GHTZ, however, has a higher magnetic response, typically $400-800$ nT greater than either the Halifax or Goldenville formation. This anomalous magnetic signature of the GHTZ confirms that the unit is a unique magnetic marker horizon at both the local and regional scales. The magnetic response of the GHTZ when constrained by the bedrock and surficial mapping indicate the inferred contact between the Halifax and Goldenville formations in this area is 500 to $1000 \mathrm{~m}$ north of the mapped contact of Horne and Corey (1994).

Previous studies by Goodwin et al. (2000) indicated a possible spatial correlation between $\mathrm{Hg}$ in soil gas and the GHTZ. Therefore, identifying the exact location of the GHTZ is impor-

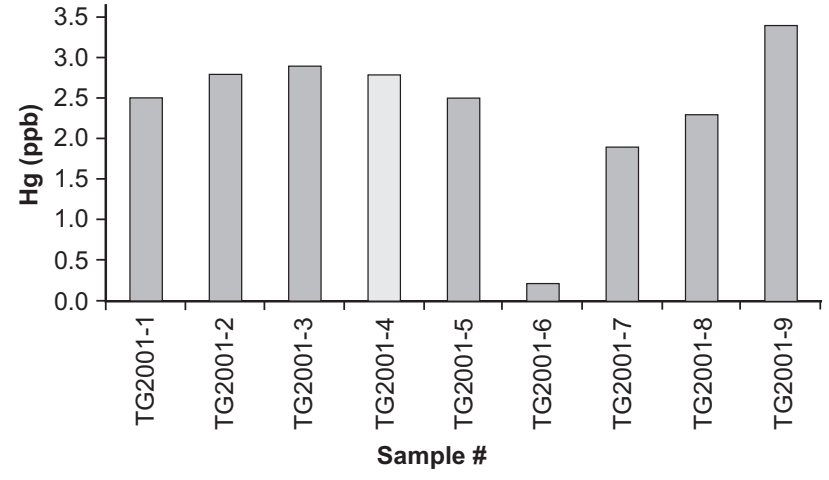

Fig. 4 Mercury concentrations ( $\mathrm{ppb}$ ) in rock samples from the study area. Range is $0.2 \mathrm{ppb}-3.4 \mathrm{ppb}$; mean $2.37 \mathrm{ppb}$; $\mathrm{n}=9 ; \sigma=0.91$. Sample 4 is greywacke, all others are slate samples.

tant when interpreting $\mathrm{Hg}$ concentrations in till. The estimated thickness (not true thickness) of the GHTZ is approximately $800 \mathrm{~m}$ based on the three transects.

\section{CONCLUSIONS}

Sampling of both bedrock and glacial till in Kejimkujik National Park(KNP), southwestern Nova Scotia, indicates that 

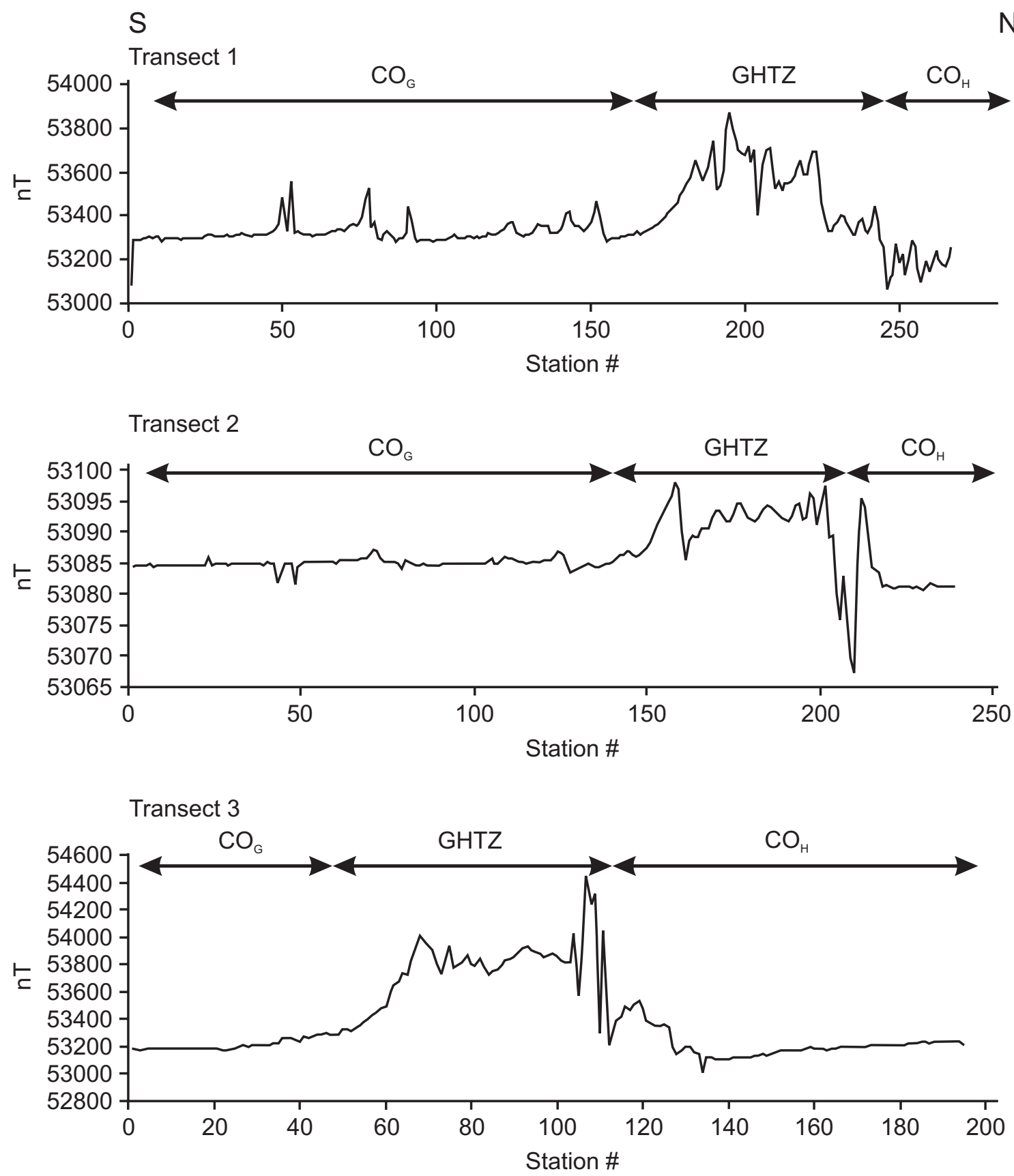

Fig. 5 Total field magnetic survey profiles along the three transects showing the interpreted position of the Goldenville Formation - Halifax Formation Transition Zone (GHTZ). Transects vary between 2.3 and $3.7 \mathrm{~km}$ in length with stations readings recorded at $12.5 \mathrm{~m}$ intervals. Bedrock geology consists of Goldenville Formation $\left(\mathrm{CO}_{\mathrm{G}}\right)$, Halifax Formation $\left(\mathrm{CO}_{\mathrm{H}}\right)$, and the Goldenville - Halifax Transition Zone.

Hg occurs naturally in both sample media. Overall, mean $\mathrm{Hg}$ in till concentrations for the Kejimkujik samples are slightly lower than mean $\mathrm{Hg}$ content for till reported by Jonasson and Boyle (1972) whereas the mean Hg concentrations in rock samples are significantly lower than mean $\mathrm{Hg}$ reported by Jonasson and Boyle (1972).
Mercury concentrations in till are the highest in the slate till facies (mean $=40.8 \mathrm{ppb}$ ) relative to the greywacke till facies (mean $=32.4 \mathrm{ppb}$ ). There is no obvious correlation between $\mathrm{Hg}$ and other analyzed elements that might indicate potential $\mathrm{Hg}$ source areas. Goodwin (2005) using a larger dataset (n=97) of till samples found that $\mathrm{Hg}$ exhibited a positive correlation with 
$\mathrm{Ga}, \mathrm{Al}$, and, to a lesser degree, $\mathrm{S}$. It remains unclear whether there is a correlation between increased $\mathrm{Hg}$ concentration and the GHTZ.

The Hg concentrations in slate and greywacke (mean $=2.4$ $\mathrm{ppb}$ ) are low but similar to previously reported values within $\mathrm{KNP}$. One explanation is that the low $\mathrm{Hg}$ results are related to $\mathrm{Hg}$ released into till and the surrounding environment during weathering processes. Studies by Sangster et al. (2001) from drill core appear to confirm a possible link to increased $\mathrm{Hg}$ concentrations with depth. Although previous reports indicated higher levels of $\mathrm{Hg}$ in sulphidic black slates, the limited rock sampling completed for this study does not support that conclusion. Mercury concentrations are highest in the samples containing the most sulphide minerals (pyrrhotite and pyrite) but the values are too low $(2.3 \mathrm{ppb}$ to $3.4 \mathrm{ppb})$ to conclude that a correlation exists.

The total field ground magnetic survey and geologic mapping indicate that the geologic contact between the Goldenville Formation and Halifax Formation is 500 to 1000 m north of that shown on the most recent published maps. Till clast identification and counts support this conclusion and also suggest that the spatial extent of the Halifax Formation in the study area is smaller than displayed on the most recent geologic maps of the area.

\section{ACKNOWLEDGEMENTS}

This paper was the basis of a B.Sc. thesis at Dalhousie University by Belinda Culgin. Health Canada provided funding for the project through the Toxic Substance Research Initiative (TSRI). Field assistance and technical support for this study were provided by the Nova Scotia Department of Natural Resources. We are grateful to the thesis supervisor, Dr. Don Fox, for his continued support of this project. We would also like to thank Michael Parkhill and Paul K. Smith for their suggestions that significantly improved the original manuscript.

\section{REFERENCES}

Burgess, N.M., \& Hobson, K.A. 2006. Bioaccumulation of mercury in yellow perch (Perca flavenscens) and common loons (Gavia immer) in relation to lake chemistry in Atlantic Canada. Hydrobiologia, 567, pp. 275-282.

Burgess, N.M., Beauchamp, S., Brun, G., Clair, T., Roberts, C., Rutherford, L., Tordon, R., \& Vaidya, O. 1998. Mercury in Atlantic Canada: a progress report. Environment Canada - Atlantic Region, 117 p.

Burgess, N.M., Evers, D.C., \& KaPLAN, J.D. 2005. Mercury and other contaminants in common loons breeding in Atlantic Canada. Ecotoxicology, 14, pp. 241-252.

Culgin, B.M. 2002. Mercury in Till and Bedrock, Kejimkujik
National Park Area, Nova Scotia. Unpublished B.Sc. thesis, Dalhousie University, Halifax, Nova Scotia, 87 p.

Finck, P.W., Boner, F.J., \& Graves, R.M. 1994. Glacial and till clast geology of Kejimkujik Lake, Nova Scotia: South Mountain Batholith Project. NTS sheets 21A/06 and part of 21A/07. Nova Scotia Department of Natural Resources, Department of Mines and Energy, Map 94-12, Scale 1: 50000.

Fox, D., Robinson, C., \& Zentilli, M. 1997. Pyrrhotite and associated sulphides and their relationship to acid rock drainage in the Halifax Formation, Meguma Group, Nova Scotia. Atlantic Geology, 33, pp. 87-103.

Goodwin, T.A. 2005. Geogenic Mercury in glacial till, Kejimkujik National Park, In Mercury Cycling in a WetlandDominated Ecosystem: A Multidisciplinary Study. Edited by N.J. O’Driscoll, A.N. Rencz, \& D.R.S. Lean, SETAC Press, Pensacola, pp. 229-249.

Goodwin, T.A, Nickel, R.J., \& Page, K.D. 2000. Mercury in till and soil gas, Kejimkujik National Park, Nova Scotia [abstract]. Nova Scotia Department of Natural Resources, Publications Report ME 2000-2. p.15.

Graves, M.C., \& Zentilli, M. 1988. The lithochemistry of metal enriched coticules in the Goldenville-Halifax transition zone of the Meguma Group, Nova Scotia. In Current Research, Part B, Geological Survey of Canada, Paper 88-1B, pp. 251-261.

Henderson, P.J., \& McMartin, I. 1995. Mercury distribution in humus and surficial sediments, Flin Flon, Manitoba, Canada, Water Air and Soil Pollution, 80, pp. 1043-1046.

Horne, R.J., \& Corey, M.C. 1994. Geological map of Kejimkujik Lake, Nova Scotia. Nova Scotia Department of Natural Resources, Mines and Energy Branch, Map sheet 21A/06 and part of 21A/07, Map 94-05, Scale 1:50 000.

Jonasson, I.R., \& Boyle, R.W. 1972. Geochemistry of mercury and origins of natural contamination of the environment, (CIM) Bulletin: Canadian Institute of Mining and Metallurgy, 65 pp. 32-39.

KING, M.S. 1997. Magnetic susceptibility mapping; applications for the Meguma Group, central Nova Scotia. In Geology and mineralogy of the Meguma Group and their importance to environmental problems in Nova Scotia, Atlantic Geology, 33, pp. 121-131.

Page, K.D., \& MurPhy, J.B. 2003. The geologic sources of Hg contamination in Kejimkujik National Park, Nova Scotia, Canada: a GIS approach, Environmental Geology, 43, pp. 882-891.

Sangster, A., Smith, P., \& Goodwin, T. 2001. Mercury content of bedrock and drill core. In Cycling of mercury in Kejimkujik National Park, Toxic Substance Research Initiative Project \#124 Summary. Environment Canada-Atlantic Region, Occasional Report no. 18, Environment Canada, Sackville, New Brunswick, pp. 49-51

Smith, P.K. 2000. Mercury and trace element geochemistry 
of selected bedrock lithologies in the Kejimkujik National Park, Southern Nova Scotia. In Multi-Disciplinary Study of Metal Cycling, Primarily Hg, in Aquatic and Terrestrial Environments. Edited by N. O'Driscoll, A. Rencz, \& T.A. Clair. First Workshop Proceedings of Kejimkujik Toxic Substance Research Initiative Work Group. Environment CanadaAtlantic Region, Occasional Report no. 15, Environment Canada, Sackville, New Brunswick. pp. 37-45.

Smith, P.K., Sangster, A.L., \& O'Beirne-Ryan, A.M. 2005. Bedrock mercury at Kejimkujik National Park, Nova Scotia, In Mercury Cycling in a Wetland-Dominated Ecosystem: A Multidisciplinary Study. Edited by N.J. O’Driscoll,
A.N. Rencz, \& D.R.S. Lean, SETAC Press, Pensacola, pp. 131-195.

SteA, R.R. 1982. Pleistocene geology and till geochemistry of south central Nova Scotia (sheet 6), Nova Scotia Department of Mines and Energy, Map 82-1, Scale 1:100 000.

Williams, G.L., Fyffe, L.R., Wardle, R.J., ColmanSADD, S.P., \& BoEHner, R.C. 1985. Lexicon of Canadian Stratigraphy Vol. VI. Atlantic Region. Canadian Society of Petroleum Geologists. Sentinel Printing, Yarmouth, Nova Scotia. 572 p.

Editorial responsibility: Michael B. Parsons 